\title{
Electrode Behavior of Iron Oxide/Carbon Nanotube Composite in Ionic Liquid Electrolyte
}

\section{Minato EGASHIRA, ${ }^{\mathrm{a}, \mathrm{b}, *}$ Yohei TSUBOUCHI, ${ }^{\mathrm{a}}$ Nobuko YOSHIMOTO, ${ }^{\mathrm{a}}$ and Masayuki MORITA ${ }^{\mathrm{a}}$}

\author{
a Graduate School of Science and Engineering, Yamaguchi University, \\ 2-16-1 Tokiwadai, Ube, Yamaguchi 755-8611, Japan \\ b Present address: College of Bioresource Sciences, Nihon University, \\ 1866 Kameino, Fujisawa, Kanagawa 252-0880, Japan
}

*Corresponding author: egashira.minato@nihon-u.ac.jp

\begin{abstract}
Composite electrode of iron oxide $\mathrm{Fe}_{2} \mathrm{O}_{3}$ and carbon nanotube has been prepared for the negative electrode of lithium batteries with ionic liquid electrolyte. The composite containing $29 \mathrm{wt} \%$ of $\mathrm{Fe}_{2} \mathrm{O}_{3}$ exhibits as large as $300 \mathrm{mAh} \mathrm{g}^{-1}$ of specific capacity in the electrolyte based on 1-ethyl-3-methyl imidazolium bis(fluorosulfonyl)amide (EMIFSA) as well as in a conventional alkylcarbonate electrolyte. When the loading of $\mathrm{Fe}_{2} \mathrm{O}_{3}$ is at as low extent as $29 \mathrm{wt} \%$, cross-linking morphology created by carbon nanotube substrate provides nano-spaces in the composite and assures mass transfer beneath electrode and thus rate capability even in viscous ionic liquid electrolyte.
\end{abstract}

(c) The Electrochemical Society of Japan, All rights reserved.

Keywords : Lithium Batteries, Ionic Liquid, Iron Oxide, Carbon Nanotube

\section{Introduction}

Ionic liquids, defined as molten salts at ambient temperature, have been attracted as novel candidates of non-flammable electrolyte component for the improvement of safety of lithium batteries. ${ }^{1-3}$ To date a number of ionic liquids have been proposed and investigated for the use in electrolyte component. ${ }^{2}$ According to great development during this decade, 1-ethyl-3-methyl imidazolium bis(fluorosulfonyl)amide (EMIFSA) appear to be attractive for practical viewpoint. ${ }^{4,5}$ The authors recognize that the main problems at present are the high cost of ionic liquid materials and the rate capability at ambient temperature of the cells containing ionic liquid electrolyte. $^{4-9}$ The cost may depend somewhat on the scale of production, and the cost of a cell can be reduced by the selection of low cost material for other parts such as electrode active mass. The high viscosity of ionic liquids, inhibiting mass transfer around electrode/electrolyte interface, is frequently assumed as low rate capability of the resulted cells. The concept of porous active material has been reported to be effective for the reduction of mass transfer resistance. ${ }^{10}$ In addition, the charge transfer process is expected to affect somewhat to the rate capability, as Cheng et al. indicates highrate performance of radical electrode even in ionic liquid electrolyte. ${ }^{11}$ The authors previously estimated the contribution of charge transfer process, ${ }^{12}$ and found that the careful selection of electrode material is important to reduce charge-transfer resistance. According to this assumption, attempts to combine various electrode materials with ionic liquid electrolyte are meaningful.

In the present study, the authors have concerned on iron oxide, $\mathrm{Fe}_{2} \mathrm{O}_{3}$, as a negative active electrode to combine ionic liquid electrolyte. $\mathrm{Fe}_{2} \mathrm{O}_{3}$ has been known to exhibit unique conversion reaction during charge-discharge process. ${ }^{13-19}$ The high theoretical specific capacity $1007 \mathrm{mAh} \mathrm{g}^{-1}$ of this electrode is also attractive for practical usage. However, $\mathrm{Fe}_{2} \mathrm{O}_{3}$ itself is an insulator and the compositing with a conductive agent is necessary for the high utilization of this active material. The authors have assumed that fibrous carbon substrates are suitable for the conductive agents, because of their high conductivity along fiber axis, high surface area providing large interface between electrode active mass/electrolyte, high chemical and mechanical stabilities. Here carbon nanotube
(CNT) is selected as compositing substrate with $\mathrm{Fe}_{2} \mathrm{O}_{3}$. Indeed, the similar iron/nano-carbon composites have been investigated for negative electrodes in aqueous alkaline batteries, and the optimization of preparation of this composite, including the selection of CNT as substrate, has been conducted. ${ }^{20}$ Here the preliminary study has been conducted in order to compare the electrode behavior of $\mathrm{Fe}_{2} \mathrm{O}_{3}$ composite in ionic liquid electrolytes with conventional alkyl carbonate electrolyte. It has been highlighted whether ionic liquid electrolyte provides similar electrode performance even under high-rate condition to conventional electrolyte, and what chargedischarge characteristics are different.

\section{Experimental}

\subsection{Preparation of iron oxide/carbon nanotube composite}

CNT (Nanocyl Inc., Belgium) was irradiated by ultrasonic in ethanol before in order to loosen aggregation, and then dispersed in $1 \mathrm{~mol} \mathrm{dm}{ }^{-3} \mathrm{HCl}$ aq. containing $\mathrm{FeCl}_{3}$ (Wako Pure Chemical Co., Japan) with prescribed ratio of $\mathrm{FeCl}_{3}$ with $\mathrm{CNT}$. The resulted suspension was neutlized by the titration of $1 \mathrm{~mol} \mathrm{dm}^{-3} \mathrm{NaOH}$ aq. to $\mathrm{pH}=8$, and filtrated by using filter paper (Toyo Roshi Co., Japan, No. 2) in order to collect $\mathrm{CNT}$ on which $\mathrm{Fe}(\mathrm{OH})_{\mathrm{x}}$ was impregnated. The collected precipitation was dried under atmospheric condition, and calcined at $773 \mathrm{~K}$ under Ar flow. The actual iron contents in the final products are checked to be similar in most cases to those expected from initial $\mathrm{FeCl}_{3}$ and $\mathrm{CNT}$ ratios by using inductive couple plasma spectroscopy (ICP; ICPE-9000, Shimadzu Co., Japan). The structures of these composites were characterized by X-ray diffraction (XD-D1, Shimadzu Co.), and their morphologies were observed by scanning electron microscope (SEM, VE-8800, Keyence Co., Japan).

\subsection{Ionic liquid electrolyte}

EMIFSA (Kanto Chemical Co., Japan) and N,N-methylpropyl piperidinium bis(trifluoromethane sulfonyl)amide (PP13TFSA; Kanto) are used as electrolyte solvents. Each ionic liquid was used as received. The electrolytes were prepared by dissolving LiTFSA (Kanto) at the molar ratio of 0.20 . The dissolving procedure was conducted in a glove box filled with argon. 

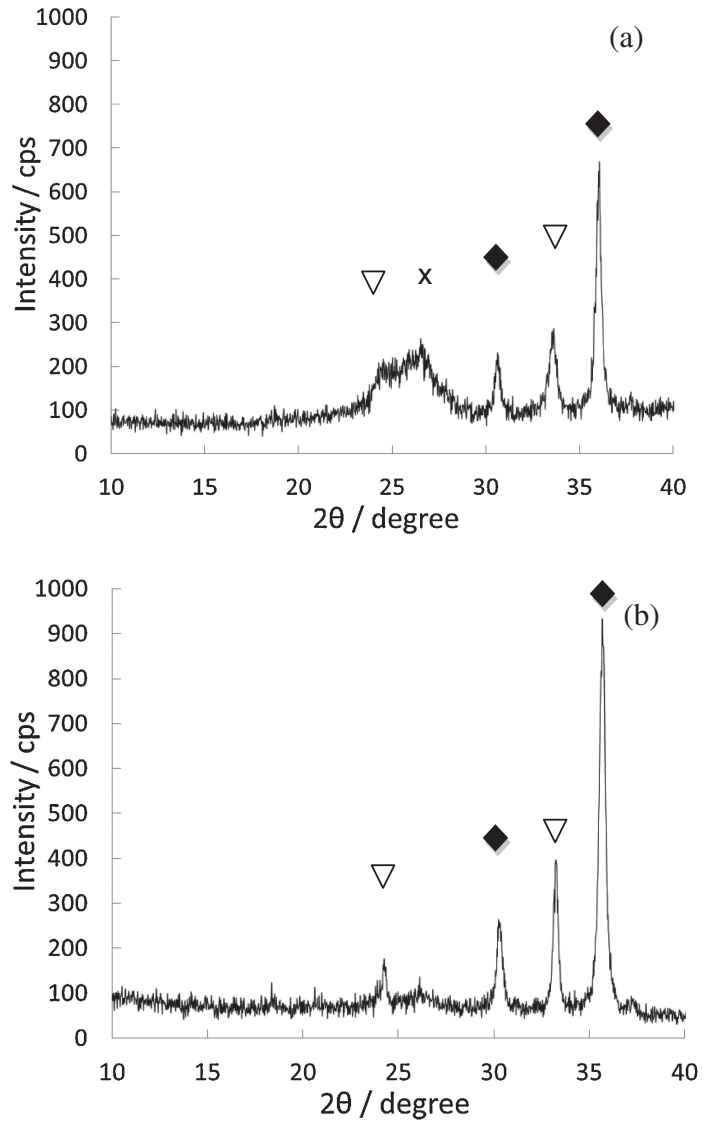

Figure 1. X-ray diffraction patterns of $\mathrm{Fe}_{2} \mathrm{O}_{3} / \mathrm{CNT}$ composites. (a) $\mathrm{Fe}_{2} \mathrm{O}_{3} 29 \%$ (b) $\mathrm{Fe}_{2} \mathrm{O}_{3} 60 \%$. Character: maghemite $\mathrm{Fe}_{2} \mathrm{O}_{3}$ $\nabla$ hematite $\mathrm{Fe}_{2} \mathrm{O}_{3} \times$ carbon $(\mathrm{CNT})$.

\subsection{Charge-discharge test}

The electrode properties of prepared $\mathrm{Fe}_{2} \mathrm{O}_{3} / \mathrm{CNT}$ composites were evaluated by constant-current charge-discharge tests. The test cell was 2032 stainless-steel sealed 2-electrode coin cell, which consisted of working electrode, lithium metal (Honjo metal Co., Japan) counter electrode, ca. $2 \mathrm{~cm}^{3}$ of electrolyte, a polypropylene separator (Celgard 2500). In most cases poly(vinylidene difluoride) (PVDF) was used as binder. The $\mathrm{Fe}_{2} \mathrm{O}_{3} / \mathrm{CNT}$ composite was suspended in $\mathrm{N}$-methylpyrrolidinone (Kanto Chemical, Japan) with 5 wt\% of PVDF (Kureha Chemical Co., Japan) followed by the processes that the suspension was spread onto copper mesh and dried under vacuum. The disk $(10 \mathrm{~mm}$ diameter) cut out from the pasted mesh was used as the working electrode. The approximate $\mathrm{Fe}_{2} \mathrm{O}_{3} / \mathrm{CNT}$ active mass on the working electrode was ca. $5 \times 10^{-3} \mathrm{~g}$. In addition to the ionic liquid electrolytes, electrolytic solution of $1 \mathrm{~mol} \mathrm{dm}^{-3} \mathrm{LiPF}_{6}$ (battery grade, Kishida Chemicals Co., Japan) in mixed solvent of ethylene carbonate (EC; Kishida) with dimethyl carbonate (DMC; Kishida) was also used as comparison. After the assembly of coin cells containing the ionic liquid electrolyte, the cells were stored overnight at $338 \mathrm{~K}$.

The charge-discharge tests for the coin cell were conducted using a constant-current cycler (BTS-2004, Nagano Co., Japan) under prescribed current densities. The cut-off voltages were from $2.0 \mathrm{~V}$ to $0.2 \mathrm{~V}$ in order to avoid the lithium intercalation in CNT. These charge-discharge tests were conducted at ambient temperature, roughly controlled at $298 \mathrm{~K}$.

\section{Results and Discussion}

\subsection{Characterization of $\mathrm{Fe}_{2} \mathrm{O}_{3} / \mathrm{CNT}$ composites}

The X-ray diffraction patterns of the $\mathrm{Fe}_{2} \mathrm{O}_{3} / \mathrm{CNT}$ composites with the $\mathrm{Fe}_{2} \mathrm{O}_{3}$ content of (a) $29 \mathrm{wt} \%$ and (b) $60 \mathrm{wt} \%$ are shown in Fig. 1. (a)

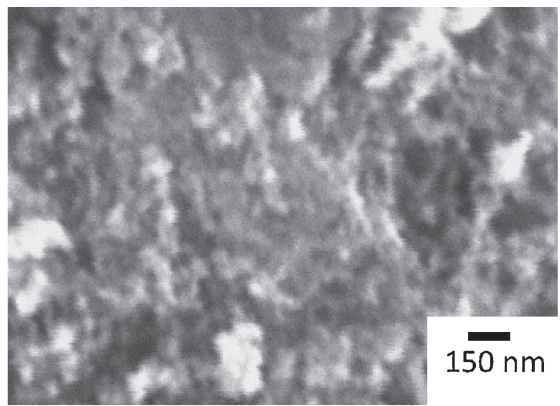

(b)

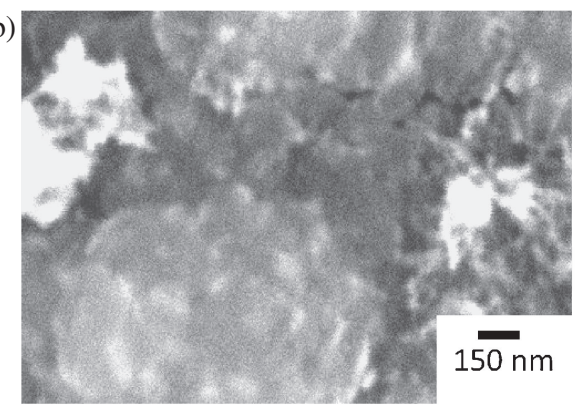

(c)

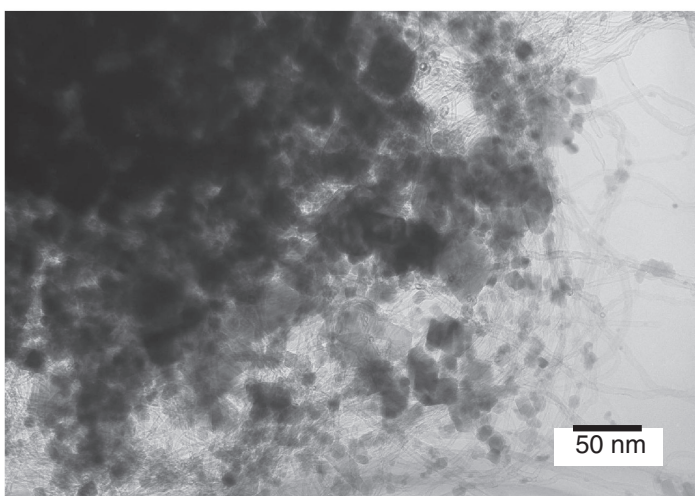

Figure 2. SEM and TEM images of $\mathrm{Fe}_{2} \mathrm{O}_{3} / \mathrm{CNT}$ composites. (a) $\mathrm{SEM}, \mathrm{Fe}_{2} \mathrm{O}_{3} 29 \%$ (b) $\mathrm{SEM}, \mathrm{Fe}_{2} \mathrm{O}_{3} 60 \%$ (c) TEM, $\mathrm{Fe}_{2} \mathrm{O}_{3} 29 \%$.

Both composites show sharp peaks at $30^{\circ}, 36^{\circ}$ assigned to maghemite $\mathrm{Fe}_{2} \mathrm{O}_{3}$ [JCPDS No. 39-1346], peaks at $24^{\circ}$ and $34^{\circ}$ assigned to hematite $\mathrm{Fe}_{2} \mathrm{O}_{3}$ [JCPDS No. 33-0664], in addition to a broad band around $26^{\circ}$ assigned to (002) of CNT. The SEM images of the $\mathrm{Fe}_{2} \mathrm{O}_{3} / \mathrm{CNT}$ composites containing $29 \mathrm{wt} \%$ and $60 \mathrm{wt} \%$ are shown in Figs. 2(a) and 2(b), respectively. While Fig. 2(a) is not clear due to the lack of resolution, it is obvious that the morphologies of these two composite is markedly different. Some sub-micron scale features may be dominated in the former SEM image. In order to help to clarify structural image of the former composite, its typical TEM image is shown in Fig. 2(c). The image indicates that particles with 2-50 nanometers are dispersed on CNT surface. In contrast, the latter SEM image provides the coverage of $\mathrm{Fe}_{2} \mathrm{O}_{3}$ on entangled CNT.

\subsection{Electrode behavior of $\mathrm{Fe}_{2} \mathrm{O}_{3} / \mathrm{CNT}$ composites}

The constant-current charge-discharge profiles of $\mathrm{Fe}_{2} \mathrm{O}_{3} / \mathrm{CNT}$ composite with $29 \mathrm{wt} \% \mathrm{Fe}_{2} \mathrm{O}_{3}$ in (a) $1 \mathrm{~mol} \mathrm{dm}^{-3} \mathrm{LiPF}_{6} / \mathrm{EC}$-DMC, (b) EMIFSA, and (c) PP13TFSA electrolytes under the current density of $0.05 \mathrm{~mA} \mathrm{~cm}^{-2}$ (approximately corresponding to $0.08 \mathrm{C}$ ) are shown in Fig. 3. In all cases reversible capacities between 200 and $600 \mathrm{mAh} \mathrm{g}^{-1}$ are exhibited after initial irreversible capacities of $1000-2000 \mathrm{mAh} \mathrm{g}^{-1}$. The initial irreversible plateau can be assigned to be the SEI formation with the reductive decomposition of electrolyte, as frequently observed in conventional electrolyte/ negative electrode interface. The plateau potential thus varies depending on the kind of electrolyte. The ionic liquid electrolytes provide plateau around $1.5 \mathrm{~V}$, higher than $1.0 \mathrm{~V}$ for $\mathrm{LiPF}_{6} / \mathrm{EC}-\mathrm{DMC}$, 

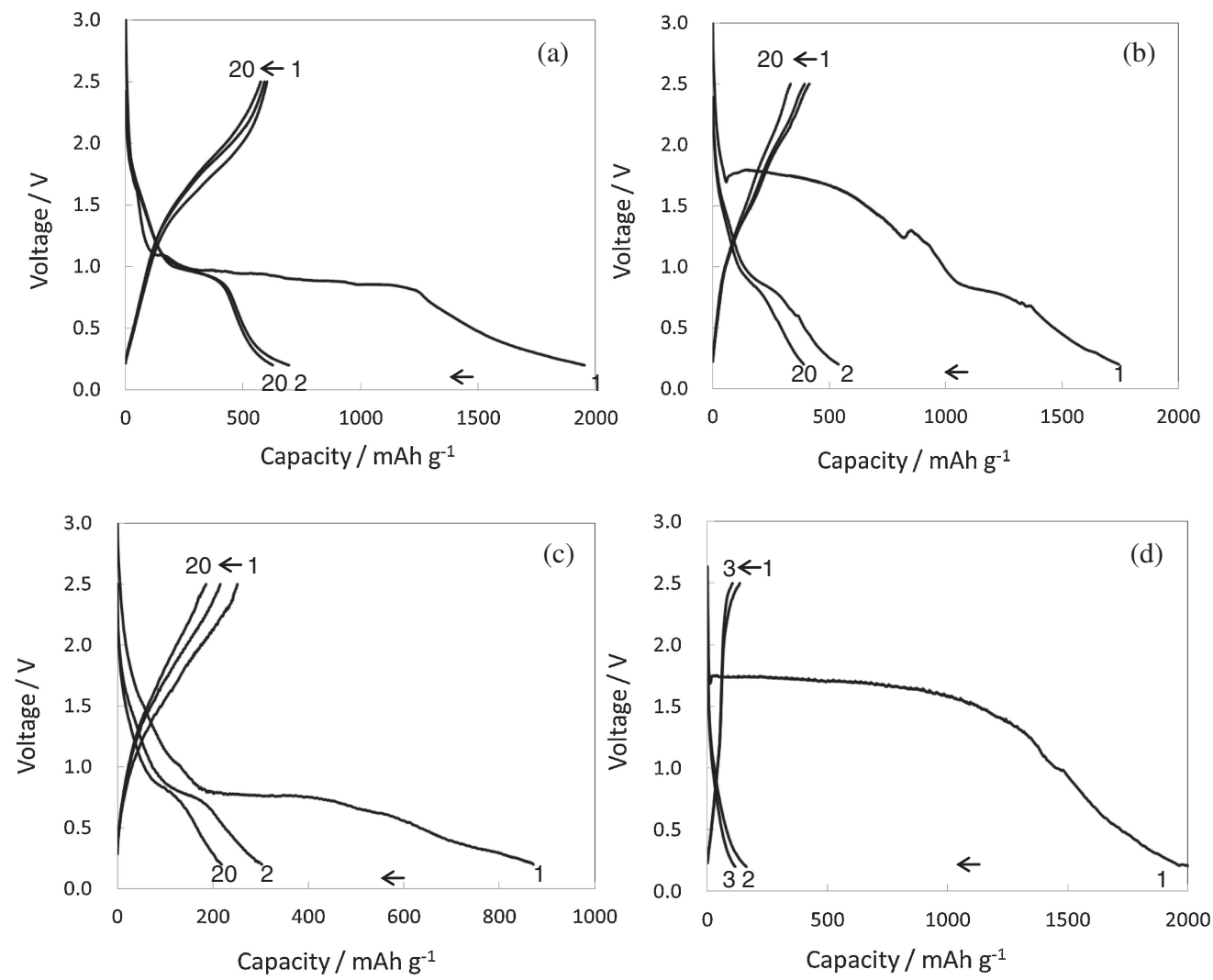

Figure 3. Charge-discharge profiles of (a-c) $\mathrm{Fe}_{2} \mathrm{O}_{3} / \mathrm{CNT}$ electrode (with $29 \%$ of $\mathrm{Fe}_{2} \mathrm{O}_{3}$ ) in various ionic liquid electrolytes and (d) CNT electrode in $\mathrm{LiPF}_{6} / \mathrm{EC}-\mathrm{DMC}$. Current density: $0.05 \mathrm{~mA} \mathrm{~cm}^{-2}$. Electrolyte: (a) LiPF $/$ EC-DMC (b) LiTFSA/EMIFSA (c) LiTFSA/ PP13TFSA.

suggesting that the ionic liquids intrinsically decompose at higher potential compared with $\mathrm{LiPF}_{6} / \mathrm{EC}-\mathrm{DMC}$.

In the all composite electrode, the plateaus are observable around $1.0 \mathrm{~V}$ vs. Li at charging (lithium insertion) process, and then leveled slopes around 0.5 to $2.0 \mathrm{~V}$ at the discharging process. The reversible capacities are based on the conversion reaction of $\mathrm{Fe}_{2} \mathrm{O}_{3}$ with lithium because such capacity is not observable when the electrode includes only CNT [Fig. 3(d)]. Bare CNT electrode having large surface area shows similarly large initial irreversible capacity.

The value of reversible capacity is larger than the expected one from the assumption of $6 \mathrm{Li}$ into $\mathrm{Fe}_{2} \mathrm{O}_{3}\left(460 \mathrm{mAh} \mathrm{g}^{-1}\right)$, probably due to the excess capacity $\left(140 \mathrm{mAh}^{-1}\right)$ by the lithium insertion in $\mathrm{CNT}$ and the contribution of double-layer discharging process. The compatibility of $\mathrm{Fe}_{2} \mathrm{O}_{3}$ active material in ionic liquid electrolytes can clearly be indicated, while the capacities are varied with the kind of ionic liquid. Such electrolyte dependence on the capacity may be mainly due to the electrolyte conductivity, wettability of electrode surface and the accessibility of viscous electrolyte in the nanopores created by nanoparticles of $\mathrm{Fe}_{2} \mathrm{O}_{3}$ and CNT. As reported previously, ${ }^{4,6}$ ionic liquids have similar conductivities (ca. $18 \mathrm{mS} \mathrm{cm}^{-1}$ for EMIFSA and ca. $1.5 \mathrm{mS} \mathrm{cm}^{-1}$ for PP13TFSA) and higher viscosities $(20 \mathrm{mPas}$ for EMIFSA and $165 \mathrm{mPas}$ for PP13TFSA) compared with $\mathrm{LiPF}_{6} / \mathrm{EC}-\mathrm{DMC}$. Indeed, the lowest rate, $0.05 \mathrm{~mA} \mathrm{~cm}^{-2}$ corresponding to $0.08 C$, can minimize the influence of the bulk resistances of PP13TFSA electrolyte. The wetting patterns of electrolyte spots on the composite electrode sheet containing $\mathrm{Fe}_{2} \mathrm{O}_{3}(29 \mathrm{wt} \%$ )/CNT (spread on aluminum foil) are shown in Fig. 4 as the indicator of the macroscopic wettability of the electrolytes. The drops of similar amounts of electrolytes provides different patterns, indicating that $\mathrm{LiPF}_{6} / \mathrm{EC}-\mathrm{DMC}$ and EMIFSA have immersed in the composite electrode more than PP13TFSA. The macroscopic wettability may mainly provide influences on the rate capabilities of $\mathrm{Li} / / \mathrm{Fe}_{2} \mathrm{O}_{3} / \mathrm{CNT}$ cells.

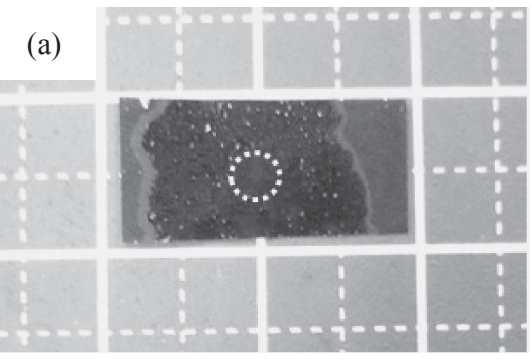

(b)

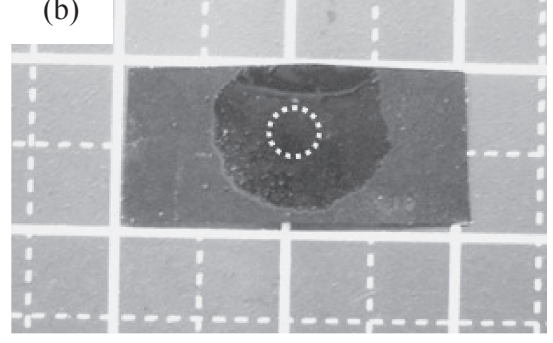

(c)

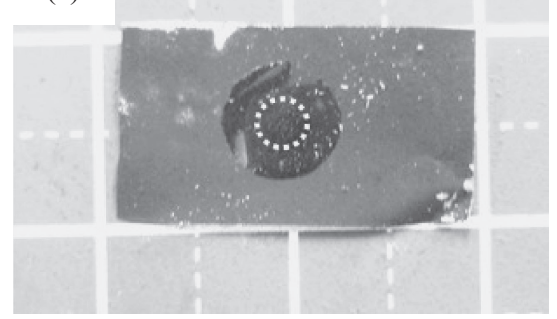

Figure 4. Photographs of wetting patterns of various electrolytes on $\mathrm{Fe}_{2} \mathrm{O}_{3}(29 \%) / \mathrm{CNT}$ electrode sheet. Electrolyte: (a) $\mathrm{LiPF}_{6} / \mathrm{EC}$ DMC (b) EMIFSA (c) PP13TFSA. Circle by broken line: mark of initial spot. 


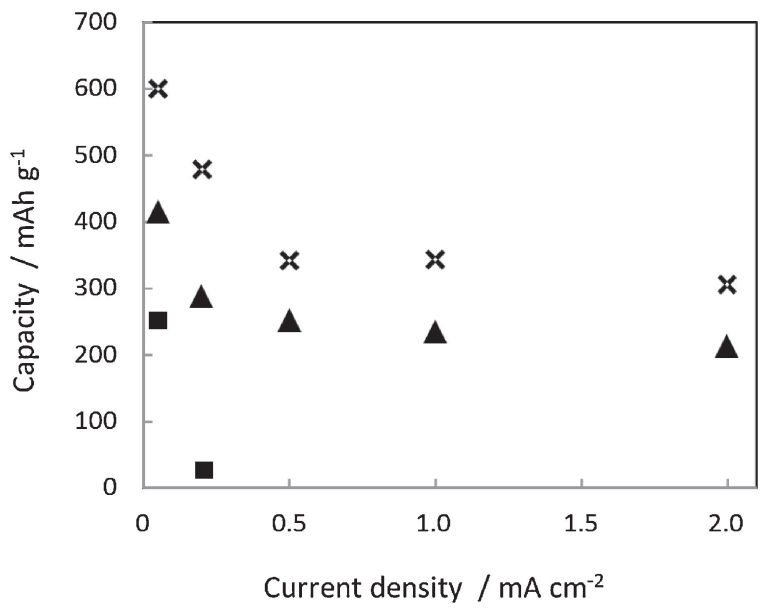

Figure 5. Dependence of specific capacity of $\mathrm{Fe}_{2} \mathrm{O}_{3} / \mathrm{CNT}$ electrode on current density in various electrolytes. *discharge capacity at 1 st cycle. Elrctrolyte: $\times \mathrm{LiPF}_{6} / \mathrm{EC}-\mathrm{DMC} \boldsymbol{\Delta}$ LiTFSA/EMIFSA 口 LiTFSA/PP13TFSA.

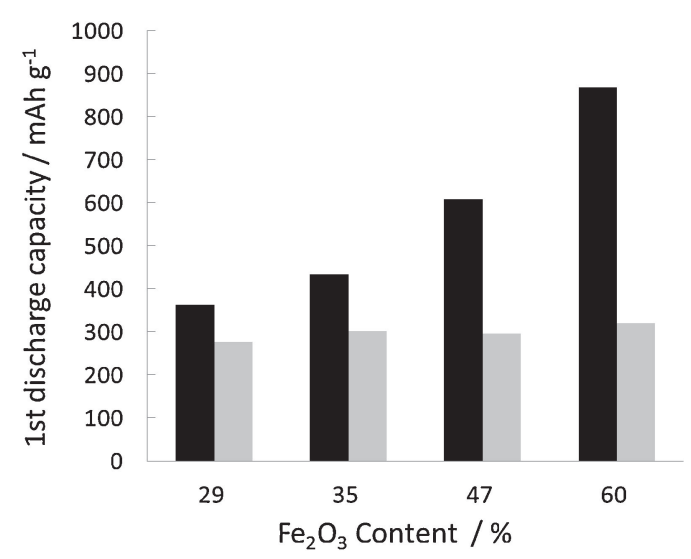

Figure 6. Dependence of $\mathrm{Fe}_{2} \mathrm{O}_{3}$ loading amount on the specific capacity of $\mathrm{Fe}_{2} \mathrm{O}_{3} / \mathrm{CNT}$ electrode in various electrolytes. (Black bar): in $\mathrm{LiPF}_{6} / \mathrm{EC}-\mathrm{DMC}$, (Grey bar): in LiTFSA/EMIFSA.

The discharge (lithium de-insertion) capacities of $\mathrm{Fe}_{2} \mathrm{O}_{3} / \mathrm{CNT}$ composite with $29 \% \mathrm{Fe}_{2} \mathrm{O}_{3}$ in various electrolytes are plotted toward the current density in Fig. 5. The $\mathrm{Fe}_{2} \mathrm{O}_{3} / \mathrm{CNT}$ electrode exhibit slight capacity loss in $\mathrm{LiPF}_{6} / \mathrm{EC}-\mathrm{DMC}$ electrolyte even by the highest current density in this figure. Similarly, EMIFSA-based electrolyte provides excellent capacity maintenance, ca. 200 $\mathrm{mAhg}^{-1}$ under high current condition. This electrode exhibits abrupt capacity decrease in the PP13TFSA electrolyte. It sounds reasonable that the PP13TFSA electrolyte having high viscosity provides severe capacity decrease at high rate. The rate capability of this composite electrode exhibits significant electrolyte dependence even among ionic liquid electrolytes, and EMIFSA provides rather good properties compared with PP13TFSA. The lower viscosity of EMIFSA compared with PP13TFSA may assure better mass transport in interfibrous spaces, and also the SEI forming in EMIFSA-based electrolyte may be more compact than that in PP13TFSA-based electrolyte as suggested by the previous reports. ${ }^{4}$

The dependences of the specific capacity (on the basis of the mass of composite) on $\mathrm{Fe}_{2} \mathrm{O}_{3}$ loading amount of $\mathrm{Fe}_{2} \mathrm{O}_{3} / \mathrm{CNT}$ electrode in $\mathrm{LiPF}_{6} / \mathrm{EC}$-EC-DMC and the EMIFSA-based electrolyte are summarized in Fig. 6. Here the applied current density was $1.0 \mathrm{~mA} \mathrm{~cm}^{-2}$, thus the capacity values involve the influence of the cell resistances. In the conventional electrolyte, the capacity increases by the increase of the $\mathrm{Fe}_{2} \mathrm{O}_{3}$ amount. The capacity is approximately proportional to the $\mathrm{Fe}_{2} \mathrm{O}_{3}$ amount. Thus, the loaded
$\mathrm{Fe}_{2} \mathrm{O}_{3}$ works in the electrolyte regardless of the morphology of composite electrode. In contrast, the specific capacities in the EMIFSA-based electrolyte are almost similar by the increase of $\mathrm{Fe}_{2} \mathrm{O}_{3}$ content. The utility of $\mathrm{Fe}_{2} \mathrm{O}_{3}$ clearly decreases in this sequence. The capacity of the composite with $29 \%$ of $\mathrm{Fe}_{2} \mathrm{O}_{3}$ indicates that $\mathrm{Fe}_{2} \mathrm{O}_{3}$ itself works even in the ionic liquid media. Therefore, such low utility of $\mathrm{Fe}_{2} \mathrm{O}_{3}$ in the composites with high loading amount is considered to be caused by the lack of the contact between $\mathrm{Fe}_{2} \mathrm{O}_{3}$ and the ionic liquid electrolyte. From Figs. 2(a) and 2(b), the pores created by intertubular spaces of CNT remains in the composite with $29 \%$ of $\mathrm{Fe}_{2} \mathrm{O}_{3}$, while $\mathrm{Fe}_{2} \mathrm{O}_{3}$ covers such pores in the one with $60 \% \mathrm{Fe}_{2} \mathrm{O}_{3}$. Such intertubular spaces may facilitate the immersion of viscous ionic liquids and provide large extent of the interface between $\mathrm{Fe}_{2} \mathrm{O}_{3}$ and the ionic liquid electrolyte in the composite with $29 \% \mathrm{Fe}_{2} \mathrm{O}_{3}$. As the loading amount increases, the intertubular spaces decreases and the creation of interface may be inhibited. From this result, it is clearly indicated that the crosslinking morphology by CNT is necessary for immersing viscous ionic liquid-based electrolyte with sufficient mass transport.

The present study has indicated that the composite electrode of iron oxide with carbon nanotube exhibiting significant capacity in ionic liquid electrolyte when the kind of ionic liquid is carefully chosen and the morphology of the composite is properly designed. The conversion reaction of $\mathrm{Fe}_{2} \mathrm{O}_{3}$ appears to be compatible in EMIFSA-based electrolyte, with sufficient rate. Indeed, the substance and the preparation method of the $\mathrm{Fe}_{2} \mathrm{O}_{3} / \mathrm{CNT}$ composite are not optimized yet, while the preparation process providing small $\mathrm{Fe}_{2} \mathrm{O}_{3}$ particles with dispersed feature has been investigated at some extent. ${ }^{20}$ The cross-linking morphology of the CNT appears to be favorable, and the discharge capacities of $\mathrm{Fe}_{2} \mathrm{O}_{3}(29 \mathrm{wt} \%) / \mathrm{CNT}$ in the EMIFSA-based electrolyte is close to the theoretical capacity of this composite under the assumption of only $\mathrm{Fe}_{2} \mathrm{O}_{3}$ acts as active mass. It is expected that the overall capacity of the composite electrode in the ionic liquid electrolyte can be improved by the increase of the loading amount of $\mathrm{Fe}_{2} \mathrm{O}_{3}$ with further modification of $\mathrm{Fe}_{2} \mathrm{O}_{3}$ dispersion on CNT. Further efforts will also be conducted to reduce initial irreversible capacity by the improvement of the coverage over CNT surface by nano-sized $\mathrm{Fe}_{2} \mathrm{O}_{3}$ more effectively.

\section{Conclusion}

The $\mathrm{Fe}_{2} \mathrm{O}_{3} / \mathrm{CNT}$ composite, prepared by the sol-gel precipitation and containing $29 \mathrm{wt} \%$ of $\mathrm{Fe}_{2} \mathrm{O}_{3}$, exhibits as high as $300 \mathrm{mAh} \mathrm{g}^{-1}$ of specific capacity under conventional charge-discharge rate even in LiTFSA/EMIFSA ionic liquid electrolyte. In this composite, $\mathrm{Fe}_{2} \mathrm{O}_{3}$ is compatible under such reaction rate in this ionic liquid electrolyte. Presently the capacity of the $\mathrm{Fe}_{2} \mathrm{O}_{3} / \mathrm{CNT}$ composite in this electrolyte does not increase even when the loading amount of $\mathrm{Fe}_{2} \mathrm{O}_{3}$ increases, due to the decrease of intertubular spaces which assure electrolyte mass transport. Further optimization of nanostructure of electrode can provide sufficient performance in ionic liquid electrolyte.

\section{Acknowledgment}

The authors thank Nanocyl Japan Inc. to provide carbon nanotube used in the present study. The TEM observation of $\mathrm{Fe}_{2} \mathrm{O}_{3} / \mathrm{CNT}$ composite has been conducted by Ms. Yumiko Kimura, JFE Technoresearch Inc., Japan.

\section{References}

1. A. Fernicola, B. Scrisati, and H. Ohno, Ionics, 12, 95 (2006)

2. A. Lewandowski and A. Świderska-Mocek, J. Power Sources, 194, 601 (2009).

3. H. Nakagawa, Y. Fujino, S. Kozono, Y. Katayama, T. Nukuda, H. Sakaebe, H. Matsumoto, and K. Tatsumi, J. Power Sources, 174, 1021 (2007). 
4. M. Ishikawa, T. Sugimoto, M. Kikuta, E. Ishiko, and M. Kono, J. Power Sources, 162, 658 (2006)

5. T. Sugimoto, Y. Atsumi, M. Kikuta, E. Ishiko, M. Kono, and M. Ishikawa, J. Power Sources, 189, 802 (2009)

6. H. Matsumoto, H. Sakaebe, K. Tatsumi, M. Kikuta, E. Ishiko, and M. Kono, J. Power Sources, 160, 1308 (2006).

7. C. S. Stefan, D. Lemordant, B. Claude-Montigny, and D. Violleau, J. Power Sources, 189, 1174 (2009)

8. N. Tachikawa, J.-W. Park, K. Yoshida, T. Tamura, K. Dokko, and M. Watanabe, Electrochemistry, 78, 349 (2010).

9. S. Fang, Y. Jin, L. Yang, S. Hirano, K. Tachibana, and S. Katayama, Electrochim. Acta, 56, 4663 (2011).

10. L. Zhao, Y.-S. Hu, H. Li, Z. Wang, and L. Chen, Adv. Mater, 23, 1385 (2011).

11. Y.-Y. Cheng, C.-C. Li, and J.-T. Lee, Electrochim. Acta, 66, 332 (2012).

12. M. Egashira, A. Kanetomo, N. Yoshimoto, and M. Morita, J. Power Sources, 196,
6419 (2011)

13. B. Di Pietro, M. Patriarca, and B. Scrosati, J. Power Sources, 8, 289 (1982).

14. M. M. Thackeray, W. I. F. David, and J. B. Goodenough, Mater. Res. Bull., 17, 785 (1982).

15. P. Poizot, S. Laruelle, S. Grugeon, L. Dupont, and J.-M. Tarascon, Nature, 407, 496 (2000).

16. D. Larcher, D. Bonnin, R. Cortes, I. Rivals, L. Personnaz, and J.-M. Tarascon, J. Electrochem. Soc., 150, A1643 (2003)

17. C. Wu, P. Yin, X. Zhu, C. OuYang, and Y. Xie, J. Phys. Chem. B, 110, 17806 (2006).

18. B. T. Hang, T. Doi, S. Okada, and J. Yamaki, J. Power Sources, 174, 493 (2007).

19. M. V. Reddy, T. Yu, C.-H. Sow, Z. X. Shen, C. T. Lim, G. V. Subba Rao, and B. V. R. Chowdari, Adv. Funct. Mater., 17, 2792 (2007)

20. M. Egashira, S. Nakayama, N. Yoshimoto, and M. Morita, Electrochemistry, 81, 473 (2014). 